\title{
Journal of English Literature and Language Research Article
}

\section{Introduction to the Study of "Kitab al-Hikayat al-'Ajiba wa-l- \\ Akhbar al-Ghariba"}

\section{Prof. Dr. Luisa Maria Arvide Cambra}

University of Almeria. Spain

*Corresponding Author: Prof. Dr. Luisa Maria Arvide Cambra, University of Almeria. Spain.

\begin{abstract}
:
The Kitāb al-Hikāyāt al-'Ajība wa-l-Akhbār al-Gharība (Book of Amazing Stories and Rare News) is an anonymous work written in Arabic that collects forty-two stories which are similar to those found included in compendia of popular Arab literature of the Middle Ages, such as The Thousand and One Nights. This article is an introduction to its study, and it includes the editions and the translations made on this interesting book as well as its narrative structure and content, according to the manuscript Istanbul Ayasofya Müzesi no.3397, edited by Hans Wehr and Alexander von Bulmerincq in 1956.
\end{abstract}

Keywords: Kitāb al-Hikāyāt al-'Ajība wa-l-Akhbār al-Gharība, Oriental Short Story, Arabic Literature, Medieval Tales, Arab Tales

The Kitab al-Hikayat al-'Ajiba wa-lAkhbar al-Ghariba

The Kitāb al-Hikāyāt al-'Ajība wa-lAkhbār al-Gharība (Book of Amazing Stories and Rare News) is an Arabic anonymous work, as is usual in this type of compilation books. It collects forty-two stories, which are similar to those found included in compendia of popular Arab literature of the Middle Ages such as The Thousand and One Nights.

This collection of forty-two stories remains in a single Arabic codex, the MS Istanbul Ayasofya Müzesi no. 3397 (XIII-XIV century), discovered by Hellmut Ritter in 1933 [1], and edited by Hans Wehr and Alexander von Bulmerincq in Damascus [2] and in Wiesbaden [3], in 1956; and later it was re-edited, in Cologne [4], in 1997, and in 2012 [5].

Only eighteen of the forty-two stories are preserved, and they include a total of twenty-six tales full of fantasy, adventure and imagination, which appear to constitute the first volume of the book.

As I have already mentioned, some of the Journal of English Literature and Language stories or legends enclosed in the pages of this work are an almost equal copy of The Thousand and One Nights's stories or, at least, very similar to them, for example: The barber's six brothers (story \#3), Jullanār the Sailor (story \#6), Abū Muhammad the Lazy (story \#11), Jubayr Ibn 'Umayr and Budūr (story \#8), etc.

The handwriting of the manuscript suggests that the copy was made around the $14^{\text {th }}$ century, but its content indicates that the stories were compiled and, in some cases, composed around the $10^{\text {th }}$ century in Syria or Egypt.

The codex dates from approximately the beginning of the $14^{\text {th }}$ century, and is therefore of the same date as the oldest known manuscript of The Thousand and One Nights used by Adolf Galland for his work in the early $18^{\text {th }}$ century [6], and which was the basis for the critical edition of Muhsin Mahdi [7].

The origin of the tale as a genre is found in the Eastern peoples, mainly India and Persia. The Arabs transmitted and enriched it with their contributions, and thus it was known in Europe. This collection of stories is framed within this framework. 
Introduction to the Study of "Kitab al-Hikayat al-'Ajiba wa-l-Akhbar al-Ghariba"

The ancient Oriental narrative of legends, tales, fables and apologues is very present in almost all Medieval and Renaissance Christian works. Many of their books were versioned in European languages, and they left important traces in later both writings and authors: Calila e Dimna, Sendebar, El Conde Lucanor of Don Juan Manuel; andDecameron of Giovanni Boccaccio, among others, are very illustrative examples.

The forty-two stories of the Kitäb alHikāyāt al-'Ajība wa-l-Akhbār al-Gharība

1. Story of King of Bahrayn

2. Story of Țalha and Țuhfa

3. Story of the six peoples

4. Story of the four searches

5. Story of the forty girls

6. Story of Jullanār the sailor

7. Story of 'Arūs al-'Arā'is

8. Story of Budūr and 'Umayr

9. Story of 'Ușfūr Abī Dīsa

10. Story of Al-Sūl and Al-Shumūl

11. Story of the sloth and the monkey

12. Story of Miqdād and Al-Mayyāsa

13. Story of Sa'īd Ibn Hātim Al-Bāhilī

14. Story of Șakhr and Khansā '

15. Story of the eulogy of the Prophet, God bless him and his family, and save him

16. Story of Muhammad Al-Mawjūd and Hārūn Al-Rashīd

17. Story of Al-Ashraf and Al-Anjab

18. Story of the enchanted mountain

19. Story of Al-Mawhūb and Al-Mahliyya

20. Story of Salmā and Al-Walīd

21. Story of the barmaki thief

22. Story of Jamīla Al-Badawiyya

23. Story of Sa'd and Hassān

24. Story of Fawz and Al-'Abbās

25. Story of Hazwa, the singer

26. Story of Ahmmad Al-Shārib

Journal of English Literature and Language
27. Story of Ardashīr Ibn Māhān

28. Story of the golden dove

29. Story of Ahmmad Al-'Anbarī

30. Story of the ebony horse

31. Story of Al-'Aqūlì

32. Story of Badr and the vizier

33. Story of Shams Al-Qușūr

34. Story of Salmān

35. Story of the bamboo island

36 . Story of the island of emeralds

37. Story of the stunned king

38. Story of King Shizarān

39. Story of Bayāḍ and Riyāḍ

40. Story of Țāhir Ibn Khāqān

41. Story of Abū-l-Faraj Al-Ișfahānī

42. Story of the girl who swallowed the blade

In the first folio of the Istanbul manuscript the forty-two stories are cited, although, as I have already said, only eighteen have been preserved, and the story no. 15 named the Tale of Prophet's eulogy is missing.

There are translations to German (story \#5) [8] [9]; English (full) [10]; French (story \#7) [11]; (stories \#5,\#9,\#14, and\#18) [12]; and Spanish (story \#3) [13].

\section{Conclusion}

The Kitāb al- Hikāyāt al-'Ajība wa-lAkhbār al-Gharība (Book of Amazing Stories and Rare News),an interesting collection of tales copied about the $14^{\text {th }}$ century, is framed into the process of origin and transmission of Oriental short stories to Europe, and so its study is very important for history of literature, since it helps to increase knowledge of this genre.

\section{References}

[1] H. Ritter. Philologika XIII: Arabische Handschriften in Anatolien und Istanbul. Oriens.1949;2: 289-295.

[2] H. Wehr \& A. von Bulmerincq. Kitāb al-Hiikāyāt al-'ajībah wa-al-akhbār al-gharībah. al-Mațba'a al-Hāshimīyah: Dimashq, 1956. 
Introduction to the Study of "Kitab al-Hikayat al-Ajiba wa-l-Akhbar al-Ghariba"

[3] H. Wehr \& A.von Bulmerincq.Kitāb al-ḥikāyāt al-'ağība wa-al-a_kbār al-garība.Franz Steiner: Wiesbaden, 1956.

[4] H. Wehr, Kitāb al-ḥikāyāt al-'ağība wa-al-a_kbār al-gaarība. Manšūrāt al-ğamal: Köln, 1997.

[5] H. Wehr. Kitab al-Hikayat al-'ajiba wa l-Akhbar al-ghariba. Al-Kamel Verlag: Köln, 2012.

[6] A. Galland. Les Mille et Une Nuits: Contes Arabes.12 vols., $1^{\text {ère }}$ édition, Paris, 1704-1717 (re-edited many times).

[7] M. Mahdi. Alf layla wa-layla min-ușūlihi al'arabiyya al-ulà. Vol.I, Leiden, 1984.

[8] O. Spies. Das Märchen von den vierzig Mädchen. Fabula. 1961; 4: 1-19.
[9] M. Weisweiler. Arabische Märchen. Vol.I, Düsseldorf-Köln, 1969, pp. 69-89.

[10] M. C. Lyons.Tales of the Marvellous and News of the Strange:A Medieval Arab Fantasy Collection. Penguin Classics: London, 2015.

[11] D. Rabeuf. Histoire de Arûs, la belle des belles, des ruses qu'elle ourdit, et des merveilles des mers et des îles.Actes Sud: Arles; Leméac: Montréal, 2011.

[12] D. Rabeuf. Histoire des quarante filles et autres contes, Actes Sud: Arles; Leméac: Montréal, 2012.

[13] L.M.Arvide Cambra. Cuentos Árabes Medievales (I). Historia de los seis individuos. VisionNet Editores: Madrid, 2020.

Citation: Prof. Dr. Luisa Maria Arvide Cambra, (2020), "Introduction to the Study of "Kitab alHikayat al-'Ajiba wa-l-Akhbar al-Ghariba"', Journal of English Literature and Language; 1(1): 1-3.

DOI: $10.31829 / 2767-2964 /$ jell2020-1(1)-101

Copyright: (C) 2020 Prof. Dr. Luisa Maria Arvide Cambra, This is an open-access article distributed under the terms of the Creative Commons Attribution License, which permits unrestricted use, distribution, and reproduction in any medium, provided the original author and source are credited. 